ljtihad, Jurnal Wacana Hukum Islam dan Kemanusiaan

Vol. 16, No. 1 (2016), pp. 1-25, doi : 10.18326/ijtihad.v16i1.1-25

\title{
Jihad dinamis: menelusuri konsep dan praktik jihad dalam sejarah Islam
}

\author{
Zakiya Darajat \\ Universitas Islam Negeri Jakarta DPK Universitas Negeri Jakarta (UNJ) \\ E-mail: rakiza.darojat.@uinjkt.ac.id \\ DOI:10.18326/ijtihad.v16i1.1-25
}

Being the most misunderstood term, jihad has been misconstrued by orientalists and Muslims alike. The misconception of jihad can be attributed to not only severely substantialist or textualist reading of the Qur'an and Hadith, but also misinterpretation of the history of jihad being in practice during the early generation of Muslims. The comprehensive reading of texts on jihad in the Qur'an and Hadith has to be accompanied by an accurate and objective reading on how jihad was put in practice by the Prophet Muhammad, the Companions and the Successors, and then how it was practiced during the subsequent periods (medieval, modern and contemporary), particularly in order to know in which context jihad has been regarded as a spiritual, ethical and moral struggle (jihad akbar), and in what kind of context it has been practiced as a physical struggle in a war (jihad asghar). In that way, jihad would not be misunderstood and, on the contrary, be appropriately connected with its contexts. The dynamics of the implementation of jihad has been influenced by different socio-historical factors, such as political realities facing Muslims in different periods. This essay seeks to explore how the practice of jihad has changed over time in Muslim history, from the time of the Prophet to the modern day Indonesia marked by vibrant Muslim movements.

Jihad menjadi terminologi yang paling sering disalahpahami, tidak hanya oleh para orientalis tetapi juga oleh kaum Muslimin sendiri. Kesalahpahaman tentang konsep jihad ini tidak hanya dipengaruhi oleh faktor pemahaman yang sangat substansialis atau tekstualis terhadap nash-nash Al-Qur'an dan al-Hadith, tetapi juga dipengaruhi oleh pembacaan yang salah terhadap sejarah praktik jihad sejak periode awal Islam. Pembacaan yang komprehensif terhadap teks-teks jihad dalam Al-Qur'an dan al-Hadits harus diharmonisasikan dengan pembacaan yang cermat dan obyektif terhadap bagaimana sejarah jihad yang dipraktikkan oleh Nabi Muhammad SAW., sahabat, tabi'in di masa klasik, berlanjut pada masa pertengahan, masa modern, hingga masa kontemporer sekarang ini. Dalam konteks apa jihad diiinterpretasikan sebagai sebuah perjuangan spiritual, etis dan moral (jihad akbar), dan dalam kondisi bagaimana jihad dipraktikkan sebagai perjuangan fisik atau perang (jihad asghar). Dengan demikian konsep jihad tidak akan disalahpahami dan akan dikorelasikan sesuai dengan konteksnya. Dinamisasi praktik jihad yang 
terjadi juga dipengaruhi oleh perbedaan faktor sosio-historis, seperti realitas politik yang dihadapi oleh kaum Muslim di setiap periode. Tulisan ini berusaha menelusuri bagaimana terjadinya dinamisasi praktik jihad dalam sejarah umat Islam, sejak masa Nabi Muhammad SAW. hingga masa pergerakan umat Islam Indonesia.

Keywords: Dynamics of jihad; Spiritual, ethical and moral struggle; Physical struggle; War

\section{Pendahuluan}

Jihad menjadi salah satu doktrin dalam Islam yang sangat krusial dan hampir tidak pernah tercapai kesepemahaman di kalangan umat Islam, apalagi di kalangan para sarjana Barat. Di bawah landasan ideologi jihad, beberapa pemimpin Islam pernah menghantarkan kekhalifahan Islam menjadi salah satu imperium terbesar dalam sejarah umat manusia yang tidak hanya maju dalam kemiliteran, tapi juga dalam penguasaan peradaban. Akan tetapi, atas nama jihad, Islam juga sering kali menjadi bulan-bulanan sebagai pembawa doktrin kekerasan akibat ulah sekelompok umat Islam yang menebar teror atas nama agama.

Ekspansi dakwah Islam yang demikian massif pada masa Khalifah Umar bin Khattab hingga Kekhalifahan Turki Usmani yang mampu menciptakan imperium terbesar adalah contoh konkret betapa doktrin jihad mampu menjadi fondasi bagi perjuangan dakwah mereka dalam menyebarluaskan Islam. Doktrin jihad mampu menggentarkan para musuh Islam ketika menyaksikan betapa para tentara Islam menyambut seruan jihad dengan penuh suka cita. Di malama hari mereka menjadi seorang ahli ibadah yang tekun, sedangkan di siang hari mereka menjelma menjadi tentara yang tak gentar menghadapi kematian di medan perang.

Akan tetapi di sisi lain, doktrin jihad juga sangat sering mengalami misinterpretated, yang oleh karena itu menjadikan Islam sebagai sasaran tuduhan di balik serangkaian kekerasan yang dilakukan segelintir orang Islam. Di Indonesia, contoh termutakhir betapa mudahnya ideologi jihad "dijual" adalah suksesnya kelompok ISIS (Islamic State of Iraq and Syiria) dalam mengecoh banyak Muslimin dari beberapa belahan negara untuk bergabung dengan gerakan yang dikomandani Abu Bakar al-Baghdadi. Satu keluarga asal Makassar rela menjual rumahnya dan berniat untuk bergabung dengan seruan jihad ISIS di Suriah. Begitu juga dengan para pemuda Muslim dari berbagai daerah di Indonesia, juga di beberapa negara Barat telah merelakan hidupnya demi berjuang bersama Jihad. Kisah Wildan Mukhollad, 
pemuda 20 tahun asal Lamongan, Jawa Timur, kakak beradik Nasir Mutsanna dan Ashil Mutsanna, Mahasiswa Fakultas Kedokteran di Inggris, Douglas McAthur McCain asal Illinois, Amerika Serikat (Mashuri, 2014: 35-38) dan ratusan pemuda lainnya yang sukses dijaring ISIS, menjadi penegasan betapa ideologi Jihad sangat ampuh digunakan oleh kelompok radikal untuk mengobarkan semangat para pemuda yang masih meletup-letup.

Jihad yang mereka pahami dan praktikkan juga telah sukses menegaskan stereotype Islam sebagai agama kekerasan. Padahal sebagaimana namanya, Islam adalah agama rabmah, agama kasih sayang. Jihad tidaklah memiliki makna tunggal. Ia bisa dimaknai dan dipraktikkan sesuai dengan kondisi yang dihadapi umat Islam. Maka, konsep jihad akbar dan jïhad asghar, menjadi pemahaman yang disepakati oleh mainstream umat Islam. Dalam situasi apa kita harus menerapkan jihad akbar dan dalam kondisi bagaimana jihad asghar mesti dilakukan. Hal ini tentu meniscayakan pemahaman yang komprehensif dari umat Islam, disertai dengan pembacaan yang jeli terhadap praktik jihad umat Islam generasi awal di bawah tuntunan Rasulullah Saw.., berlanjut ke masa-masa sesudahnya.

\section{Jihad dalam pandangan dua lelompok Muslim}

Oleh para orientalis, konsep jihad yang secara etimologi memiliki makna kerja keras dan kesungguh-sungguhan, hampir selalu diidentikkan dengan qital (bunuh), harb (perang, war), bahkan irhab (terorisme). Edmund Bosworth tanpa pandang bulu memberi kesimpulan bahwa aktivitas politik kaum Muslim selama lebih dari 12 abad di wilayah Turki, Iran, Sudan, Ethiopia, Spanyol, dan India bertitik tolak dari seruan jihad belaka (Said, 1997; 114). Demikian juga dengan Robin Wright yang menggambarkan konsep jihad sebagai Perang Salib versi Islam. Ia bahkan sampai pada kesimpulan bahwa kata jihad adalah slogan bagi orang Islam untuk menegakkan agama tahuid terakhir di dunia, di bawah ancaman pedang, atas orang-orang kafir (Johnson, 1997: 64).

Faktanya, tidak hanya para orientalis yang berpandangan bahwa jihad identik dengan harb ataupun qital. Sebagian ulama klasik, baik para fuqaba (ahli hukum), mutakallimin (ahli teologi) dan mubaddithin (ahli hadith), hampir saja selalu memaknai kewajiban jihad sebagai kewajiban militer (Lewis, 1988: 72). Sedangkan bagi para sufi asketis klasik, meski memaknai jihad sebagai latihan spiritual yang mengarahkan jiwa dari kecenderungan keinginan duniawi 
serta bertujuan mensucikan jiwa dan membuka tabir kemunafikan yang mungkin merintangi menuju jalan Allah, mereka tetap tidak menafikan konsepsi militer tentang jihad. Perjuangan batin menundukkan elemen dasar jiwa seseorang merupakan sebuah refleksi perjuangan untuk menundukkan elemen dasar jiwa masyarakat seperti anarki dan kekerasan. Untuk itu, elemen dasar ini harus dimurnikan, dan bila perlu dengan menggunakan kekuatan demi kehidupan yang harmoni sesuai petunjuk Allah Swt. Pada prinsipnya, dalam pandangan para sufi, jihad batin merupakan prakondisi penting untuk jihad fisik, agar perjuangan bisa didasarkan pada tujuan yang luhur, bukan berdasarkan pada motivasi yang keliru (Heck, 2004: 95). Pada perkembangan selanjutnya, jihad telah mengalami penyempitan makna (pejoratif), dan mungkin juga kehilangan essensi ketika ia selalu saja dihubungkan dengan segala tindak kekerasan, perang, dan bahkan aksi terorisme.

Paling tidak, umat Islam terbelah menjadi dua dalam memaknai konsep jihad. Pertama adalah mereka yang berpandangan bahwa jihad hanya memiliki makna tunggal, yaitu perang. Mereka yang masuk dalam kategori kelompok ini antara lain adalah kelompok salafi jihadis. Mentor kaum salafi jihadis seperti Hasan Al-Banna, Sayyid Qutb, 'Abdullah 'Azzam, Ayman al-Zhawahiri dan sebagainya menolak otensitas hadith yang mengatakan bahwa jihad akbar atau perjuangan spiritual melawan hawa nafsu lebih bermakna daripada jihad asghar atau perang melawan musuh Islam. Bagi kelompok ini penafsiran bahwa perang (melawan musuh Islam) termasuk kategori jihad kecil sengaja diciptakan para musuh Islam untuk mengkerdilkan semangat umat Muslimin dalam melawan musuh-musuh Islam yang sampai saat ini masih mencengkeram beberapa wilayah Muslim. Pemahaman bahwa jihad hanya memiliki makna tunggal yaitu jihad fisik (perang) ini pulalah yang kemudian dianut oleh para generasi salafi selanjutnya. Para pelaku Bom Bali seperti Imam Samudra, Mukhlas, Amrozi dan sebagainya misalnya, memegang teguh makna jihad menurut empat Imam Mazhab yang memaknai jihad sebagai tindakan fisik. Bagi mereka, makna harfiyah tidak bisa dipakai sebagai landasan dalam pelaksanaan aktivitas ibadah umat Muslim, melainkan harus merujuk kepada makna syar'i (Samudra, 2004: 107-108). Karena itu, merekapun memaknai peristiwa Bom Bali sebagai operasi jihad, khususnya dalam melawan hegemoni AS dan Barat, yang selama ini mereka nilai banyak menebar aksi kekerasan di beberapa wilayah Muslim seperti Afghanistan, Irak, Palestina, dan sebagainya. Dalam analisis Azyumardi Azra, bentuk revolusioner 
jihad kelompok ini bertujuan untuk membuktikan bahwa jihad merupakan tindakan yang absah untuk mencapai cita-cita Islam (Azra, 1996: 137).

Meski demikian, al-Banna tetap mengakui bahwa ada yang lebih membahayakan dari sekedar kampanye militer dan politik dalam perjuangan jihad. Pada tahun 1920-an ia mengecam gelombang ateisme dan hal-hal kotor lainnya yang melanda Mesir sebagai awal kehancuran agama dan moral dengan dalih kebebasan individu dan kebebasan intelektual. Pendiri al-Ikhwan al-Muslimun ini menyerang Rupert Murdoch dan Barry Diller serta kaum westernis lainnya yang telah mengimpor wanita setengah telanjang beserta dengan minuman keras, teater, tari-tarian, novel, cerita, permainan tolol, dan sifat-sifat buruk lainnya ke negerinya. Fenomena moworld ini telah merenggut superioritas ilmu pengetahuan dan bersifat merusak melebihi militer. Al-Banna memberikan warning bahwa budaya Barat jauh lebih berbahaya daripada kampanye militer dan politik (Barber, 1996: 210).

Kelompok kedua adalah mainstream umat Islam yang memaknai jihad tidak hanya berbentuk jihad fisik (perang), melainkan yang lebih besar lagi adalah jihad melawan hawa nafsu (jihad akbar). Kelompok ini, antara lain Muhammad Abduh, Rasyid Ridha, Yusuf alQaradhawi, dan di Indonesia antara lain Muhammadiyah, NU, MUI, dan sebagainya, berpandangan bahwa jihad melawan hawa nafsu justru lebih berat dibandingkan dengan perang. Jika jihad perang, musuh jelas terlihat, juga ada batasan waktu dan tempat dalam melaksanakan jihad. Sedangkan jihad melawan hawa nafsu, musuh tidak terlihat dan harus dilakukan sepanjang waktu dan di manapun berada. Termasuk dalam jihad akbar adalah memerangi kebodohan, kemiskinan, kezaliman, korupsi, sifat tamak, haus kekuasaan, perilaku boros, tidak disiplin, dan perilaku negatif lainnya. Dalam bingkai pemikiran seperti inilah Muhammadiyah kemudian menggulirkan ide Jihad Konstitusi, sebagai bagian dari upaya mengoreksi peraturan perundang-undangan yang dinilai sangat pro-asing, dan sebaliknya, tidak memihak kepada kepentingan rakyat kecil. Meski demikian, kelompok ini tidak menafikan jihad dalam arti fisik. Dalam sejarah pergerakan Indonesia, Nahdlatul Ulama (NU) pernah menyerukan Resolusi Jihad pada tanggal 22 Oktober 1945 yang memiliki implikasi besar bagi perlawanan Arek Soroboyo dalam melawan tentara sekutu pada peristiwa 10 November 1945. Demikian juga Muhammadiyah yang menyerukan dukungan terhadap tentara Sabilillah milik Masyumi dalam melawan sekutu yang mencoba ingin kembali menjajah 
ljtihad, Jurnal Wacana Hukum Islam dan Kemanusiaan, Volume 16, №. 1, Juni 2016: 1-25

Indonesia. Akan tetapi, kelompok ini menolak keras kegiatan teror yang mengatasnamakan jihăd fi sabilillăh seperti yang sempat marak terjadi di tanah air beberapa waktu yang lalu. Menurut Azyumardi Azra inilah model jihad rasional-apologetik yang bertujuan untuk membuktikan bahwa Islam bukanlah agama kekerasan dan perang (Azra, 1996; 137). Jihad perang hanya dilakukan ketika musuh menganggu missi Islam atau menyerang umat Muslim, atau dengan kata lain hanya demi tujuan defensif.

\section{Praktik jihad pada masa Rasulullah Saw. dan generasi berikutnya}

Untuk menghindari kesalahpahaman terhadap konsep jihad, ada baiknya ditelaah lebih mendalam bagaimana Rasulullah Saw.. sang uswah hasanah (teladan yang baik) dalam mempraktikkan konsep jihad. Sejatinya, perintah berjihad sudah turun pada periode Mekkah. Lihat misalnya QS. al-Furqan (25): 52, “Maka janganlah kamu mengikuti orang-orang kafir dan berjihadlah terhadap mereka dengan Al-Qur'an dengan jïhad yang benar “. Atau QS. al-Ankabut (29): 6 dan 69: "Dan barang siapa berjïhad, maka sesunggubnya jïhadnya itu untuk dirinya sendiri"; 'Dan orang-orang yang berjïhad (untuk mencari keridhaan) Kami, benar-benar akan kami tunjukkan kepada mereka jalan-jalan kami. Dan sesungguhnya Allah benar-benar beserta orang-orang yang berbuat baik". Faktanya, pada periode Mekkah ini umat Islam belum terlibat dalam aksi peperangan melawan kafir Quraisy. Oleh karena ketika itu umat Islam secara struktur sosial, politik dan ekonomi masih dalam kondisi yang lemah, maka makna perintah berjihad pada periode Mekkah ini lebih ditekankan pada perintah untuk bersabar, baik sabar dalam menghadapi segala bentuk intimidasi dan siksaan yang mereka terima dari kaum kafir, maupun sabar dalam mempertahankan aqidah. Artinya, perintah berjihad pada periode Mekkah lebih bermakna perjuangan spiritual, etis dan moral demi mendekatkan diri kepada Allah SWT dan menundukkan nafsu dengan bersabar, yang hakikat dan hikmah dari jihad itu sejatinya untuk umat Muslim sendiri (QS. 29:6).

Perintah berjihad yang diwujudkan dalam tindakan fisik (perang) barulah dilakukan pertama kali oleh Rasulullah SAW. pada periode Madinah, tepatnya dua tahun pasca hijrahnya Umat Muslimin dari Mekkah ke Madinah, yaitu pada Perang Badar yang terjadi pada 17 Ramadhan 2 H/17 Maret 623 M. Tindakan memerangi kaum kafir inipun ditempuh karena mereka tak henti-hentinya menebarkan permusuhan, intimidasi dan menghalangi dakwah Islam. 
Jihad perang dilakukan ketika umat Islam secara struktur politik, sosial dan ekonomi dirasa sudah cukup mapan dan kuat. Artinya, jihad perang bukanlah realisasi dari tindakan offensif, melainkan semata-mata sebagai tindakan defensif demi menjaga hak dan martabat umat Muslim, dan dilakukan dengan tetap memperhatikan etika perang, tidak melampaui batas (QS. 22:39, 2:190), disertai dengan pembacaan yang cermat terhadap kekuatan yang telah dimiliki umat Islam. Lihat misalnya QS. al-Hajj (22): 39, "Telah diizinkan berperang bagi orangorang yang diperangi, karena sesunggubnya mereka telah dianiaya. Dan sesunggubnya Allab benar-benar Maha Kuasa menolong mereka itu”. Juga QS. al-Baqarah (2): 190, " Dan perangilah di jalan Allah orang-orang yang memerangi kamu, tetapi janganlab kamu melampaui batas, karena seunggubnya Allah tidak menyukai orang-orang yang melampaui batas". Etika perang yang diwasiatkan Rasulullah Saw.. kepada pasukan Islam antara lain tidak mengganggu perempuan, anak-anak, manula, para pendeta, warga sipil, dan tempat ibadah.nabi juga melarang mengambil apapun dari mereka kecuali dengan membayarnya, serta melarang menyembelih hewan piaraan mereka kecuali hanya sebatas untuk makan saja (Enizar, 2002: 138).

Begitu juga ketika terjadi peristiwa Fath Mekkah (penaklukkan kota Mekkah) pada tahun ke-8 Hijriyah, Rasululah Saw. dan umat Muslimin yang telah memiliki kekuatan tak tertandingi di Jazirah Arab tidak memperlihatkan kepongahan, arogansi ataupun melampiaskan balas dendam kepada kaum kafir atas penderitaan dan siksaan yang dahulu mereka alami pada periode Mekkah. Rasulullah Saw. bahkan kemudian memberikan amnesti besar-besaran kepada penduduk Mekkah dan memberi jaminan rasa aman kepada mereka.

Perintah berjihad pada periode Madinah tidak mesti berkonotasi perang. Dalam banyak hadith Rasulullah Saw. menegaskan beberapa aktivitas yang dikategorikan sebagai tindakan jihad, antara lain menyampaikan kalimat yang haq di depan pemimpin yang culas, berbakti kepada kedua orang tua, ibadah haji dan umrah, berjuang melawan hawa nafsu karena Allah, dan lain sebagainya.

Dari sini kita bisa menyimpulkan, bagaimana Allah Swt. memberikan tahapan-tahapan bagi umat Muslimin dalam menerapkan konsep jihad melawan kaum kafir. Tahapan pertama, ketika kondisi mereka belum memiliki kekuatan yang signifikan pada periode Mekkah, Allah memerintahkan umat Muslim untuk berjihad dengan bersabar dan dengan menggunakan al-Qur'an. Kemudian tahapan kedua setelah umat cukup kuat, mereka diberi 
opsi untuk berperang demi mempertahankan diri dan melindungi diri mereka. Tingkatan jihad terakhir ketika Nabi dan pengikutnya telah kuat keimanan dan pasukannya untuk menaklukkan Kota Mekkah pada tahun 630 M, barulah dikatakan kewajiban dan tugas mereka untuk berjuang sampai tidak ada lagi fitnah dan kemusyrikan (Roshandel dan Chadha, 2007: 46).

Pada periode sejarah umat Islam berikutnya, diskursus perang sebagai salah satu bentuk jihad tampak semakin mengkristal. Hal ini dilatarbelakangi oleh situasi dan kondisi yang mengharuskan umat Islam melakukan tindakan tersebut. Pasca wafatnya Rasulullah Saw. pada tahun ke-11 Hijriyah/632 M, terjadi gerakan pemurtadan yang dilakukan beberapa kabilah Arab. Mereka juga melancarkan pemberontakan dan tidak mau lagi membayar zakat. Karena itu, jihad pada masa kepemimpinan Abu Bakar as-Shiddiq ra ditujukan untuk memadamkan bughat (pemberontakan) ini. Demikian juga pada masa kekhalifahan Umar bin al-Khattab ra, di samping jihad demi memperluas dakwah Islamiyah, ia juga banyak melakukan jihad pemikiran (ijtihad), antara lain menciptakan kalender Hijriyah sebagai permulaan penanggalan Islam, membuat mata uang emas, mendirikan baitul mal, membagi wilayah kekuasaan Islam ke dalam beberapa provinsi, membentuk korps tentara, mengatur gaji pegawai, dan masih banyak lagi.

Pada masa Khalifah Utsman bin Affan, ideologi jihad mampu membuktikan ketangguhan armada angkatan laut pasukan Islam yang dipimpin Gubernur Muawiyah bin Abi Sufyan, hingga pada tahun $28 \mathrm{H}$, kekuasaan Islam mampu menembus Pulau Siprus dan Rhodes dan mengalahkan penguasa Romawi. Daerah-daerah lain di Afrika Utara seperti Barqah, Tripoli, Nubia, dan Tunisia juga berhasil dikuasai. Demikian juga beberapa wilayah Asia Tengah seperti Baktria, Kabul, Ghazna, dan Turkistan, berhasil ditaklukan pasukan Muslim di era Uthmān bin Affān. Ide pembentukan armada angkatan laut ini sendiri dilatarbelakangi oleh adanya serangan angkatan laut tentara Romawi ke wilayah Syam, yang dipimpin Gubernur Muawiyah bin Abi Sufyan.

Sementara itu, diskursus tentang jihad pada masa Daulah Umayyah dan Abbasiyah tidaklah jauh berbeda dengan masa al-Khulafāa al-Räsyidūn. Jika pada masa al-Khulafáa al-Räsyidūn pemahaman jihad lebih banyak teraplikasikan dalam bentuk praksis, maka pada masa 'Umayyah, terutama masa Abbasiyah, diskursus tentang jihad sudah menjadi kajian teoritis 
para intelektual Muslim, baik ulama fiqih, ulama hadith, sufi, filosof, dan sebagainya. Euben mencatat bahwa doktrin tentang jihad telah dikodifikasi dalam ilmu pengetahuan hukum pada pertengahan abad ke-8, yaitu bertepatan dengan periode penaklukan Muslim terbesar (Euben, 2002: 13).

Berdirinya Bani 'Umayyah (661-750 M) menandakan awal munculnya sistem monarki dalam kekhalifahan Islam. Muawiyah telah mengubah sistem pemerintahan demokratis era al-Khulafä al-Rāyidūn menjadi turun temurun. Meski mengundang kontroversi di awal kekuasaannya, Daulah ini telah memberikan prestasi dan kontribusi gemilang bagi sejarah Islam. Pada masa ini, hegemoni politik, militer dan pengaruh Islam di luar Jazirah Arab mencapai prestasi yang mencengangkan. Atas prestasinya ini, Philip K. Hitty menyebut Mu'awiyah tidak saja sebagai raja pertama, tetapi juga raja Arab terbai. (Hitty, 1970: 246).

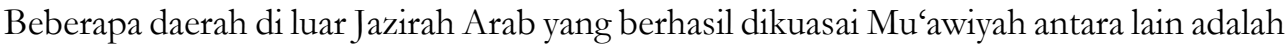
Tunisia. Di sana ia mendirikan kota Qairawan yang kelak menjadi salah satu pusat kebudayaan Islam. Di sebelah timur, ia menguasai Khurasan hingga Sungai Oxus, dan Afghanistan sampai Kabul. Angkatan laut Muawiyah bahkan dapat melakukan serangan sampai ke ibu kota Byzantium, Konstantinopel. Ekspansi Muawiyah juga sukses mencapai Afrika Utara. Para penerus Muawiyah bahkan mampu memperluas kemenangan menembus daratan Eropa. Salah satu panglimanya, lariq bin Ziyad berjasa besar dalam penaklukan Eropa. Ia berhasil menyeberangi Selat Gibraltar (Jabal Tariq) dan mengalahkan tentara Raja Roderick dari Andalusia (Spanyol saat itu). Tercatat kota-kota di Andalusia yang bisa ditaklukkan pasukan Islam antara lain Toledo (ibu kota Andalusia), Sevilla, Malaga, Elvira, dan Cordoba (Watt, 1990: 25).

Meski tradisi keilmuan pada masa Daulah 'Umayyah kurang menonjol, akan tetapi beberapa ulama terkenal lahir pada masa ini. Khalid bin Barmak (w.708 M) adalah Muslim pertama yang menerjemahkan buku-buku berbahasa Yunani dan Koptik tentang kimia, kedokteran, dan astrologi. Dari kalangan ahli Hadith dan hukum muncul Hasan al-Bacri dan Ibnu Shihab al-Zuhri (w.742 M). Dari kalangan penyair antara lain ada al-Akhtal dan Jamil (w.710 M). Sedangkan di bidang seni arsitektur, Dome of The Rock di Yerussalem adalah karya monumental dari Daulah 'Umayyah.

Daulah 'Abbasiyah berkuasa hampir selama 5 abad (750-1258 M). Meski masih diwarnai serangkaian konflik politik, akan tetapi Daulah ini telah menorehkan tinta emas dalam sejarah 
ljtihad, Jurnal Wacana Hukum Islam dan Kemanusiaan, Volume 16, No. 1, Juni 2016: 1-25

peradaban Islam. Al-Mansur, khalifah pengganti Abu al-'Abbas, pada bulan Shaffar 146 H/762 M memindahkan ibu kota kekhalifahan dari Damaskus pada masa Umayyah, ke Baghdad, sebuah kota yang dialiri Sungai Eufrat dan Tigris yang sangat cocok bagi kemaharajaan 'Abbasiyah. Nama resmi kota ini adalah Madinatussalam, Kota Perdamaia. (Watt, 1990: 103).

Pada masa 'Abbasiyah, terutama pada masa kekhalifahan Harun Al-Rasyid (786-809 M) dan dilanjutkan anaknya, Al-Ma'mun (813-833 M), Islam menjadi pusat peradaban dunia, bahkan ketika dunia Barat sedang dalam keadaan masti suri (The Dark. Age). Kecintaannya kepada ilmu pengetahuan mengantarkan masa kekhalifahannya mengalami apa yang disebut sebagai masa keemasan, The Golden Age, terutama di bidang ilmu pengetahuan dan peradaban. Pada masa ini, lahir banyak intelektual Muslim dari berbagai bidang keilmuan, baik filsafat, hukum, ilmu hadith, kedokteran, fisika, astronomi, arsitektur, geografi, sejarah, matematika, dan sebagainya.

Pada masa inilah kajian teroritis tentang jihad mengalami perkembangan yang sangat signifikan. Ia tidak hanya menjadi bahan diskusi para ahli hukum dan hadith, tetapi juga para filosof dan sufi. Di antara diskursus yang berkembang dalam pemikiran mereka antara lain adalah tentang jihad dan kewajiban imam (pemimpin negara). Menurut mereka, Islam berkewajiban menjalankan misi utamanya yaitu menegakkan supremasi firman Allah di atas dunia yang dibawa dan disebarkan dengan jihad. Untuk meningkatkan kebijakannya, imam menegakkan hukum yang mengatur hubungan antara umat dengan mereka yang bukan umat, baik pada masa perang maupun masa damai, memutuskan kapan jihad dilakukan dan kapan jihad harus dihentikan. Dalam menjalankan hubungan luar negeri, imam mendelegasikan kewenangannya kepada para komandan di lapangan atau gubernur untuk bernegosiasi, menjalankan jihad, dan membagi harta rampasan perang (Khadduri, 2006: 124).

Madjid Khadduri mencatat bahwa sejalan dengan kebangkitan intelektual maupun filsafat Islam pada abad keempat Hijriyah atau abad ke-10 Masehi, telah terjadi pergeseran konsepsi jihad dari aktif menjadi perang pasif yang menjauhkan umat Islam dari ekspansi lebih jauh, yaitu ketika umat Islam lebih memusatkan perhatian kepada kontroversi antara paham ortodoks dan rasionalis daripada berperang melawan Byzantium yang melanggar garis 
perbatasan. Dengan diperkuat pendapat Ibnu Khaldun yang mengatakan bahwa rileksasi atas jihad menandai perubahan karakter dari bangsa yang suka berperang menjadi bangsa yang beradab, selanjutnya Khadduri menyimpulkan bahwa perubahan konsep jihad ini tidak semata-mata tindakan menutupi kelemahan dan kegagalan untuk menjunjung tinggi doktrin, akan tetapi lebih kepada proses evolusi yang dituntun oleh kepentingan maupun berbagai kondisi sosial masyarakat Islam (Khadduri, 2006: 65-66).

Selain masa keemasan, pertengahan terakhir masa Daulah 'Abbasiyah ditandai dengan masa disintegrasi. Harun Nasution mencatat bahwa masa disintegrasi terjadi pada tahun 1000-1250 M, ditandai dengan pecahnya keutuhan umat Islam di bidang politik. Demikian juga khilafah sebagai lambang kesatuan politik umat Islam menjadi hilang hingga Hulagu Khan menghancurkan Baghdad pada tahun 1258 (Nasution, 1995: 5). Kekuasaan khalifah di Baghdad hanyalah boneka saja. Sementara di beberapa daerah, para sultanlah yang secara real berkuasa. Pada masa-masa inilah hingga awal abad ke-20, jihad sering digunakan sebagai panggilan untuk tindakan radikal melawan kekuasaan yang tidak legitimate. Ibnu Taymiyyah menyerukan kewajiban revolusi melawan penguasa yang melampaui atau meninggalkan hukum Islam. Karena itu, sejarah mencatat, mulai dari Bani Almoravid abad ke-11, jihad Sholahuddin melawan kaum Salib pada abad ke-12 (Perang Salib berlangsung dari tahun 1095-1291 M, pada tanggal 7 Juni 1099 tentara Salib berhasil menguasai Jerussalem, akan tetapi pada 2 Oktober 1189 Shalahuddin al-Ayyubi berhasil merebut kembali Baitul Maqdis.dari tentara Salib), jihad melawan suku-suku kafir dan penguasa Spanyol, jihad di Kurdistan melawan penguasa Timurid, dan awal abad ke-16 jihad sebagai kekuatan antikolonial (Euben, 2002: 14-15).

Di abad pertengahan, Imperium 'Uthmaniyyah dikenal sebagai imperium ghaza. Para khalifah Dinasti Uthmaniyyah dalam analisa Turner Johnson telah mempraktikkan gagasan asli tentang jihad dalam konteks ketatanegaraan yang dikembangkan para ahli hukum klasik, yaitu tidak hanya perang defensif untuk mendesak mundur Perang Salib, tetapi juga perang ofensif untuk memperluas där al-Isläm sebagai bentuk jihäd $\bar{f} \bar{\imath}$ sabilillăh yang dituntut dari semua Muslim.(James Turner Johnson, 1997). Selanjutnya, Turner menegaskan bahwa Perang Suci atau ghaza merupakan pondasi dari Negara 'Uthmaniyyah. Dinasti ini sangat bersungguhsungguh dalam menjalankan kewajiban melindungi dan memperluas kekuasaan Islam, dan 
bahkan berusaha untuk membenarkan tuntutan mereka untuk menguasai seluruh dunia Islam. Puncak ghaza 'Uthmāniyyah melawan Byzantium adalah ditaklukkannya Konstantinopel oleh Sultan Mehmed II pada tahun 1453 M. ${ }^{1}$ Keberhasilan mereka melawan Byzantium yang disatukan dengan komitmen menyebarkan Islam, menjadi dasar untuk merebut kepemimpinan atas där al-Isläm itu sendiri. Dengan cara inilah mereka membangun landasan bagi perkembangan imperium 'Uthmaniyyah (Johnson, 1997). Pada masa Dinasti 'Uthmani ini pula, kota Belgrad yang menjadi basis terdepan dalam perang melawan Austria, diberi nama Negara Jihad (dār al-jibād) (Lewis,1988: 34).

Konsepsi jihad yang dipraktikkan umat Islam pada periode klasik dan periode pertengahan paling tidak menggambarkan beberapa pola hubungan antara otoritas religio-politik dunia Islam dengan praktik jihad. Pertama, pada masa Islam klasik, khalifah yang merepresentasikan dirinya sebagai penerus Nabi memiliki satu-satunya otoritas yang sah untuk memimpin jihad, yang konsepsinya langsung berasal dari Al-Qur'an dan Hadith Nabi. Perang ofensif dilakukan melalui jihad melawan para pengganggu kedamaian Islam seperti kaum bid'ah, mereka yang murtad, dan mereka yang menyimpang. Kedua, jihad dan otoritas memimpin jihad berasal dari para ahli hukum klasik, tetapi mengambil bentuk baru dalam perang untuk mengusir tentara Perang Salib. Tokoh seperti Nuruddin dan Solahuddin al-Ayyubi melakukan perang defensif dalam jihad yang bertujuan merebut kembali wilayah-wilayah yang sebelumnya masuk dalam dàr al-Islam. Ketiga, adalah konsep jihad yang mengambil bentuk tradisi ghaza yang dipraktikkan para Sultan 'Uthmāniyyah, yaitu jihad ofensif yang bertujuan memperluas kekuasaan Islam (Johnson, 1997: 245-247).

\section{Praktik jihad umat Islam Indonesia}

Dalam konteks sejarah pergerakan Islam di Indonesia, ideologi jihad muncul beriringan dengan upaya membendung kolonialisme dan imperialisme yang dilakukan Bangsa Barat.

\footnotetext{
${ }^{1}$ Keberhasilan Sultan Mehmed II atau Sultan Muhammad Al-Fatih (1451-1484 M) menaklukkan Konstantinopel memudahkan ekspansi 'Uthmaniyyah ke Benua Eropa. Pada masa Sultan berikutnya, yaitu Sultan Salim I (1512-1520 M) dan Sultan Sulaiman al-Qanuni (1520-1566 M) wilayah kekuasaan Turki 'Uthmani mencapai Asia Kecil, Armenia, Irak, Siria, Hijaz, dan Yaman di Asia, lalu Mesir, Libia, Tunis dan Aljazair di Afrika, dan Bulgaria, Yunani, Yugoslavia, Albania, Hongaria, dan Rumania di Eropa. Lihat Badri Yatim, Sejarah Peardaban Islam..., 132.
} 
Kedatangan mereka ke Nusantara pada abad ke-16 dengan membawa missi gold, glory and gospel ${ }^{2}$ segera menerbitkan perasaan permusuhan di kalangan bangsa Indonesia, terutama umat Islam beserta para tokoh agamanya. Sejarah mencatat, Perang Sabil pertama di Nusantara terjadi pada awal abad ke-16 M ketika Kerajaan Kristen Portugis, melalui panglima perangnya bernama Alfonso de Albuquerque, pada tahun 1511 melakukan agresi militer terhadap Kerajaan Islam Malaka yang saat itu diperintah Sultan Mahmud Syah I (1488-1511 M) ( Muhammad. 2013: 96).

Menyatunya motif ekonomi (gold) dan motif agama (gospel) dalam missi imperialisme ini terlihat dalam ucapan Alfonso kepada anak buahnya ketika menyerbu Kota Malaka, setelah membakar semua kapal Arab dan Cambay di pelabuhan, dan menyelamatkan kapal milik orang China dan non-Muslim.

“...jasa yang akan kita berikan kepada Tuhan kita dengan mengusir orang Moor (IslamArab) keluar dari negeri ini adalah memadamkan api dari agama Mohammet, sehingga pi itu tidak akan pernah lagi menyebar sesudah itu. Saya yakin benar, jika kita rampas perdagangan Malaka ini dari mereka, Kairo dan Mekkah akan hancur...”.(Algadri, 1984: 76-77).

Tercatat beberapa perlawanan di daerah antara lain Perang Jawa, Perang Paderi, Perang Aceh, perlawanan Haji Wasidi di Cilegon, dan sebagainya, adalah beberapa perang yang menjadikan faktor religiusitas dan semangat anti penjajahan kafir dalam bingkai ideologi jihad (Perang Sabil), sekaligus menjadi faktor integratif yang mampu memobilisir rakyat dan ulama dalam mempertahankan diri. Seruan jihad melawan kolonialisme Belanda banyak disuarakan oleh oleh para ulama di berbagai daerah, yaitu seperti yang dilakukan Yusuf alMaqassari pada abad ke-17, Haji Abdul Karim, Haji Tubagus Salim Haji Mardjuki, dan Haji Wasid yang memimpin pemberontakan Banten pada tahun 1888. Demikian juga dengan seruan jihad yang digelorakan Abdussamad al-Palimbani pada abad ke-19 (Steenbrink, 1984:

\footnotetext{
${ }^{2} 3 \mathrm{G}$ (gold, glory and gospel) adalah istilah yang digunakan bagi kampanye imperialisme pada abad ke-15. Tujuan penjelajahan adalah untuk mencari sumber-sumber kekayaan (gold), berupa emas, rempah-rempah, dan sebagainya. Selain itu, kerajaan-kerajaan Eropa juga berkeinginan untuk memperluas imperiumnya dengan mendirikan koloni dan menjajah tempat-tempat baru demi memperoleh kejayaan (glory). Dalam armada penjelajahan ini juga diikutsertakan para missionaris yang menjalankan missi zending untuk menyebarkan ajaran-ajaran Kristus (gospel) di wilayah yang menjadi daerah jajahannya.
} 
ljtihad, Jurnal Wacana Hukum Islam dan Kemanusiaan, Volume 16, No. 1, Juni 2016: 1-25

32-57), serta Hadratussyaikh Hasyim Asy'ari pada abad ke-20, tepatnya tahun 1945. Semua seruan jihad ini ditujukan untuk melawan kolonialisme Belanda

Dalam Perang Jawa yang dipimpin Pangeran Diponegoro dan Kyai Mojo (1825-1830), Peter Carey melihat gerakan Diponegoro ini sebagai Perang Sabil melawan penjajah karena adanya unsur dan motivasi agama dalam perang ini. Carey merasa heran dengan banyaknya kyai dan santri yang terlibat dalam perang Jawa ini,' antara lain 108 kyai, 31 orang haji, 15 syaikh, 12 pegawai penghulu keraton Yogyakarta, dan 12 kyai guru. Pengaruh Kyai Mojo, ulama terkenal asal Surakarta, juga Kyai Baderan, Kyai Kwaron dan Kyai Hasan Besari diyakini sebagai unsur yang sangat efektif dalam memobilisir kaum santri ini. Selain itu, pribadi Pangeran Diponegoro yang aslinya bernama Bendara Raden Mas Mustahar, juga dikenal sangat religius. Ibunya, Raden Ayu Mangkarawati, adalah seorang anak kyai dari Tembayat, sedangkan pengasuhnya adalah anak seorang kyai dari Sragen. Untuk mengukuhkan posisinya tidak hanya sebagai pemimpin sosial tetapi juga pemimpin agama, Diponegoro menyandang gelar sebagai Sultan Ngabdulkamid Herucakra Kabirulmukminina Kalifatul Rasulullah Hamengkubuwono Senapati Ingalaga Sabilullah ing Tanah Jawa (Carey, 2007: $69,72)$.

Sementara itu, Perang Aceh yang terjadi sekian lama yaitu lebih dari 30 tahun, oleh Clifford Geertz disebut sebagai santri insurrection. Dalam perang inilah Belanda merasakan betapa sulitnya Aceh ditundukkan. Seorang ahli Islam dan bahasa Arab dari Universitas Leiden yang ditugaskan pemerintah Belanda untuk menyelidiki faktor penyebab sulitnya pemberontakan Aceh dipadamkan, yaitu Prof. Dr. Christian Snouck Hurgronye (1. 1857) menyimpulkan bahwa faktor agama dan ulama-lah penyebabnya (Veer, 1985: 251).

Untuk menggelorakan semangat umat Islam Aceh dalam melawan kolonial Belanda, rakyat Aceh membuat Hikayat Perang Sabil, yaitu kumpulan syair yang berisi anjuran untuk ikut aktif dalam perang. Hikayat Perang Sabil konon adalah karya Teungku Chik Pante Kulu bernama Haji Muhammad. Berikut sepenggal isi dari Hikayat Perang Sabil: (Steenbrink, 1984: 68):

“..Inilah hikayat Perang Sabil, disuruh melakukan perang sabilullah-firman Allah Yang Maha Suci, firman Allah dalam Al-Qur'an-nampak sangat nyata wahai akhi. (Quran 9,112). Ingat hai mukmin akan firman Tuhan, perintah Tuhan robbul 'alamin- Tuhan 
membeli mukmin untuk memerangi kafir. Tuhan bukan membeli mukmin untuk beribadat- bukan pula untuk bekerja mencari rezeki- semua mukmin sudah dibeli-ingatlah wahai adik yang bernasib baik- Tuhan membeli harta dan nyawa- untuk kita gunakan pada Perang Sabil- Tuhan telah membeli dengan harga mahal untuk harga surga yang maha tinggi- hendaklah bersuka hati dan bergembira-melebihi daripada hak yang diberi oleh Allah.."

Semangat jihad terus bergelora pada masa revolusi kemerdekaan ketika para ulama menyerukan Resolusi Jihad demi memberikan dukungan moril para pemimpin bangsa yang tampak gamang menghadapi tentara sekutu yang berniat kembali mencengkeram bumi pertiwi. Dalam pertempuran 10 November 1945 yang heroik inilah umat Islam dari berbagai komponen seperti Muhammadiyah dan NU, bersatu dalam tentara Sabilillah dan Hizbullah yang dikomandani para kyai melawan penjajah sampai titik darah penghabisan. Para kyai ini mencanangkan bahwa menjadi kewajiban individu (fardhu 'ayn) bagi setiap Muslim untuk mempertahankan kedaulatan wilayah Indonesia ketika musuh telah berupaya kembali menginjakkan kaki dan menjajah tanah air. Resolusi Jihad ini diseru oleh para kyai NU pada tanggal 22 Oktober 1945 dan kembali dipertegas oleh Masyumi pada tanggal 7 November 1945.

Di awal era Orde Lama, gerakan Darul Islam yang diprakarsai Kartosoewirjo pada tanggal 7 Agustus 1945, berdiri di atas landasan hijrah dan jihad. Menurutnya, kunci kemenangan perjuangan Nabi Saw. adalah dua hal ini. Maka dengan hijrah dan jihad, umat Islam Indonesia bisa meraih kemenangan. Jihad dalam pemikiran Karto tidaklah sekedar perang, tetapi juga melawan hawa nafsu (al-Chaidar, 1999; 411). Meski gagal mendirikan Negara Islam Indonesia seperti yang dicita-citakannya, ideology jihad terus dipegang teguh oleh para generasi penerus dan kader didikan Kartosoewirjo. Mereka antara lain membentuk Komando Jihad, gerakan yang bernuansa radikal, atas nama jihad yang bercita-cita mendirikan Daulah Islamiyah. Pada periode tahun 1976-1978 beberapa eks-kader DI seperti Adah Djaelani, Danu Muhammad Hasan, Haji Ismail Pranoto (Hispran), Gaos Taufik, dan sebagainya yang merupakan tokoh Komji, menciptakan instabilitas keamanan negara dan jihad melawan pemerintah Indonesia. Aksi ini merupakan protes terhadap maraknya kemaksiatan di tengah masyarakat. 
Selanjutnya pada masa awal reformasi, ideologi jihad sebagai legitimasi tindakan perang kembali muncul pada konflik horizontal yang terjadi di Maluku. Menghadapi upaya yang dianggap sebagai genosida atas warga Muslim oleh warga Kristen, serta menyadari tidak hadirnya institusi negara dalam konflik horizontal ini, pada akhirnya memunculkan inisiatif dari beberapa elemen masyarakat untuk bergerak membantu saudara-saudara mereka yang dianggap telah menjadi korban kebrutalan kelompok masyarakat yang lain, yang sebenarnya masih sama-sama anak bangsa Indonesia. Pada saat kondisi seperti inilah lahir Laskar Jihad pimpinan Ja'far Umar Thalib dari Forum Komunikasi Ahlussunah wal Jama'ah (FKAWJ) yang dibentuk pada sebuah acara tabligh akbar di Yogyakarta pada Januari 2000.

Selain Laskar Jihad, gerakan Islam Indonesia yang berdiri di atas landasan ideology jihad adalah Majelis Mujahidin Indonesia (MMI) yang berdiri pada 7 Agustus 2000. MMI merupakan organisasi yang secara genealogis maupun ideologis sangat dekat dengan gerakan Darul Islam bentukan Kartosoewirjo (Fealy, 2004: 113). Meski tokoh-tokohnya sangat dekat memiliki afilisi dengan DI/TII, akan tetapi MMI telah mengubah pola perjuangannya menjadi perjuangan yang lebih persuasive. Penegakkan syariah Islam (tǟbiqus shari $\bar{c} a b)$ di Indonesia secara komprehensif (kaffah) merupakan motivasi dan tujuan utama didirikannya MMI. Bagi MMI hal inilah yang menjadi satu-satunya solusi bagi bangsa Indonesia untuk bisa keluar dari krisis multidimensi yang mendera bangsa Indonesia.

Tidak hanya di Maluku, konflik horizontal maupun vertical yang terjadi dan melibatkan umat Islam atas nama jihad juga terjadi di beberapa tempat lain di Indonesia. Seperti yang sudah penulis kemukakan di atas, beberapa kelompok radikal fundamentalis menebar teror dengan dalih berjihad. Baik mereka yang tergabung dalam kelompok Bom Bali eks anggota Jamaah Islamiyah (JI), dan kini yang termutakhir adalah kelompok yang berafiliasi ke ISIS. Lagi-lagi, karena mereka memaknai ideology jihad semata-mata sebagai tindakan fisik atau perang.

\section{Titik seteru konsep jihad}

Terjadinya ketidaksepahaman umat Islam dalam memaknai konsep jihad ini bisa dianalisis dari dua perspektif. Mainstream umat Islam Indonesia yang antara lain direpresentasikan Muhammadiyah dan NU tetap meyakini bahwa konsep jihad bisa dimaknai sesuai dengan 
konteks yang dihadapi Umat Islam. Maka selain jihad asghar (perang) yang harus diterapkan ketika umat Islam dalam kodisi perang, akan tetapi jihad akbar (jihadun nafsi) adalah jihad yang lebih utama.

Sebaliknya, kalangan Islam salafi lebih memaknai jihad secara fisik sebagai jihad yang paling utama. Teks-teks Al-Qur'an dan Hadith tentang keutamaan jühäd $\bar{f}$ sabillilläh menjadi pegangan hidup mereka, sehingga mereka akan selalu mencari di belahan bumi mana yang bisa dijadikan sebagai tempat untuk berjihad. ${ }^{3}$ Mereka meyakini benar pendapat para mentor perjuangan jihad seperti Hasan Al-Banna dan Sayyid Quthb yang menegaskan bahwa Hadith tentang jihäd al-nafs adalah palsu dan hanya digunakan oleh para musuh Islam untuk melemahkan perjuangan umat Islam dalam mempertahankan aqidah dan där al-Isläm.

Interaksi komunitas salafi jihadis Indonesia dengan pemikiran-pemikiran Hasan al-Banna dan Sayyid Quthb, tokoh al-Ikhwanul al-Muslimun (IM) Mesir, tidak hanya terjadi melalui buku-buku kedua tokoh tersebut yang pada era 80-an banyak diterbitkan di Indonesia, akan tetapi juga melalui perjumpaan langsung mereka dengan beberapa tokoh IM yang pada tahun 1980 didatangkan oleh Lembaga Pendidikan Bahasa Arab (LPBA) yang didirikan Universitas Islam Imam Muhammad bin Saud, Riyadh, di Jakarta. Selain program pendidikan Bahasa Arab, lembaga ini juga melakukan program kerjasama dengan pesantren-pesantren di Indonesia untuk menyediakan dosen-dosen tamu. Atas rekomendasi Dewan Dawah Islamiyah Indonesia (LDII) pimpinan Mohammad Natsir, LPBA mengirimkan dosen-dosen untuk mengajar di Pesantren Ngruki. Salah satu tokoh IM yang mengajar di Ngruki adalah Syaikh Khalim Khamada, aktivis IM asal Irak. Dari sinilah terjadi interaksi yang intens antara tokoh IM, juga kitab-kitab tokoh-tokoh IM seperti buku Sayyid Hawwa tokoh IM asal Syiria, Fï Ziläl al-Qurán karya Sayyid Quthb, juga buku Usroh karya Hasan al-Banna, dengan komunitas salafi jihadis Indonesia, yang antara lain banyak di antara mereka adalah alumnus Pesantren Ngruki (Solahudin, 2011: 151).

\footnotetext{
${ }^{3}$ Setelah hengkangnya Rusia dari bumi Afghanistan, 'Abdullâh 'Azzam telah memfatwakan bahwa medan jihad berikutnya adalah wilayah kaum Muslim yang saat itu diduduki orang kafir, seperti Palestina, Kashmir, juga Moro, Filipina. Sedangkan menurut Ayman al-Zhawahiri, medan jihad berikutnya adalah pemerintahan masing-masing mujahidin yang belum mau menegakkan syariat Islam. Lihat Solahudin, NII Sampai JI; Salafi Jihadisme di Indonesia, (Jakarta:Komunitas Bambu, 2011), 210.
} 
Selain pengaruh pemikiran toko-tokoh IM ini, pengalaman empirik komunitas salafi jihadis terjun langsung di medan jihad semakin mengkristalkan pemahaman dan keyakinan mereka tentang jihad aktif (perang-qitāh), jih $\bar{a} d \bar{f}$ sabillillăh sebagai jihad yang paling utama. Di medan jihad di Afghanistan dan Pakistan, mereka tidak hanya mendapatkan pendidikan kemiliteran tetapi juga pemahaman tentang konsep jihad dan tauhid langsung dari mentor perjuangan jihadis internasional seperti 'Abdullah 'Azzam, ${ }^{4}$ Ayman al-Zhawahiri, Syaikh Rassul Sayyaf, juga Usamah bin Laden. Jihad dan tauhid tidak semata-mata menjadi pengetahuan teoritis semata, akan tetapi di medan perang, dua hal ini menjadi sangat praktis bagi kaum jihadis ini. Doktrin taubid rububiyah, mulkiyah dan ulubiyah, bahwa Allah sajalah dzat yang maha memelihara, maha menguasai, dan satu-satunya yang berhak disembah benar-benar merasuk dalam keyakinan mereka. Selain itu, kekaguman mereka terhadap kepribadian tokohtokoh jihadis internasional ini, ditambah dengan pengalaman-pengalaman emosional-spiritual, bahkan keajaiban yang mereka alami di medan jihad, menjadikan mereka sangat menikmati perjuangan jihad ini dan bahkan merasa ketagihan dan kecanduan dengan perjuangan jihad. ${ }^{5}$

Di Indonesia, kesenangan mereka terhadap perang yang mereka maknai sebagai jihad pada akhirnya tersalurkan dalam beberapa momentum, antara lain di Maluku melawan kaum Kristen yang memerangi umat Islam, demikian juga di Poso. Selain itu, doktrin dari mentor mereka di Afghanistan tentang kafir ijnaby dan kafir mahaly sebagai bagian dari

\footnotetext{
${ }^{4}$ Salah seorang pelaku Bom Bali I, Imam Samudra, telah mengenal pemikiran-pemikiran jihad 'Abdullâh 'Azzam sejak usianya masih belia, 16 tahun, melalui bukunya yang berjudul Ayātur Rahmān fì jihäadi Afghânistan (Tanda-tanda Kekuasaan Allah dalam Jihad di Afghanistan). Sejak membaca buku 'Azzam ini, Imam Samudra mengaku selalu terobsesi untuk bisa sampai ke Afghanistan demi menjadi salah satu syuhada. Afghanistan saat itu, dalam pandangan kaum mujahidin adalah negeri para syuhada. Tahun 1990-an, obsesi Imam Samudra ini menjadi kenyataan. Lihat Imam Samudra, Aku Melawan Teroris (Solo: Jazeera, 2004), 41.

${ }^{5}$ Ali Ghufron (Mukhlas), veteran pejuang Afghanistan melukiskan pengalaman heroismenya di medan perang Afghanistan dengan ungkapan, "menurut pengalaman dan perasaan saya, tidak ada sejengkal bumi yang pernah saya pijak lebih menyenangkan, mengasyikkan dan menggairahkan dibandingkan dengan medan perang. Atau dalam bahasa lain, An-ni'matu là ya'rifubà illa man dhäqobā, kenikmatan yang tidak dapat dirasakan selain orang yang sudah mengalaminya". Kecanduan perang ini juga dirasakan para jihadis lainnya. Lihat Solahudin, NII Sampai JI, 209.

${ }^{6}$ Kafir ijnaby adalah orang kafir asing yang menduduki dan menjajah wilayah Muslim, sedangkan kafir mabaly atau kafir tempatan adalah penguasa yang mengaku Islam tetapi tidak mau menjalankan syariat Islam. Memerangi kafir mahaly dianggap sebagai jibad difa'i dan hukumnya fardlu 'ain.
} 
perjuangan jihad tetap hidup dalam keyakinan mereka. Inilah yang menyebabkan mereka terus mengibarkan bendera perlawanan terhadap AS dan sekutunya yang meraka anggap telah melakukan penjajahan di beberapa negara Muslim termasuk Indonesia, juga terhadap pemerintahan yang mereka anggap sebagai taghut sekaligus antek Barat. Di antara kaum salafi jihadis ini juga banyak yang berangkat ke Palestina, Suriah, dan Irak, baik untuk membantu para pejuang Muslim maupun untuk menjalankan misi kemanusiaan.

Pemahaman kaum salafi jihadis tentang jihad ini tentu berbeda secara diametral dengan pemahaman mayoritas umat Islam Indonesia yang lebih memaknai jïăadun nafsi sebagai jihad yang paling utama. Semula, memang kaum salafi ini memiliki pemahaman yang sama dengan pemahaman jihad yang dianut mainstream umat Islam Indonesia, bahwa jihad memiliki makna luas yaitu melakukan segala kebaikan yang sesuai dengan ajaran Islam. Akan tetapi, interaksi mereka dengan komunitas jihadis internasional di Afghanistan telah menggeser pemahaman jihad mereka. Merujuk kepada pendapat empat Imam mazhab, yaitu Hanafi, Hambali, Maliki dan Syāfi $\bar{i}$, bahwa secara syar $i$ pengertian jihad hanyalah qitäl. Sedangkan pengertian jihad sebagai upaya sungguh-sungguh dalam hal kebaikan adalah pengertian lughowi. Dalam pemahaman mereka, pengertian lughowi tidak bisa dijadikan sebagai rujukan dalam beribadah. Dalam hal ibadah, kita hanya bisa merujuk kepada makna syari (Samudra, 2004: 69). Perbedaan pemahaman tentang jihad inilah yang menjadi titik seteru antara kaum salafi jihadis dengan mainstream umat Islam Indonesia.

Hal kedua yang menjadi titik seteru dalam gerakan sosial Islam Indonesia adalah tentang batasan där al-harb dan där al-Islàm, juga klasifikasi jihad defensif (jïhäd difai 'i) dan jihad ofensif (jihäd hujumı) sekaligus hukum melakukan kedua jihad ini, apakah fardu 'ain ataukah fardu kifayah. Dalam pandangan Hasyim Asy'ari, jihad qitäl (perang) hanya boleh dilakukan ketika musuh memasuki wilayah Muslim. Maka wilayah Muslim yang sebelumnya adalah dâr al-Isläm, ketika sudah diduduki musuh telah bisa diklasifikasikan sebagai där al-harb. Perang dilakukan sebagai bagian dari jihad defensif dan hukumnya adalah fardu 'ain bagi mereka yang berada pada radius $94 \mathrm{~km}$ dari wilayah harb. Artinya, jihad defensif ini memiliki batasan teritorial dan waktu yang jelas. Sebaliknya, NU tidak sepakat jika ketika Indonesia dalam kondisi damai kemudian dijadikan sebagai där al-harb ketika oleh sebagian kalangan pemerintahannya dianggap maghut karena tidak mau menegakkan syariat Islam. Dalam 
ljtihad, Jurnal Wacana Hukum Islam dan Kemanusiaan, Volume 16, №. 1, Juni 2016: 1-25

pandangan NU, mereka yang melakukan perang atas wilayah Islam dikategorikan sebagai irhab (teror). Dalam sejarahnya, di bawah pendudukan kolonial Belanda, NU bahkan pernah menyebut Indonesia sebagai dār al-Islam, negoro Islam, dalam pengertian wilàyatul Islam, bukan daulah Islam. Karena meskipun pemerintah kolonial Belanda adalah kafir, akan tetapi umat Islam diberi keleluasaan untuk menjalankan aktivitas keagamaannya dengan baik.

Muhammadiyah memiliki pandangan yang serupa dengan NU perihal där al-Isläm dan dār al-harb ini. Bahwa bagaimanapun, Indonesia sekarang ini tidak bisa dimasukkan dalam kategori där al-harb, karena secara fisik Indonesia tidak sedang mengalami penjajahan. Oleh karena itu, Muhammadiyah menyatakan sangat mengutuk tindakan pengeboman yang dilakukan segelintir orang Islam terhadap beberapa rumah ibadah umat lain, juga tempattempat lain, dengan anggapan bahwa Indonesia sudah bisa dikategorikan sebagai där alharb, dengan dalih jihad melawan umat Kristen, atau AS dan Barat. Namun demikian, Muhammadiyah tetap memandang bahwa secara ekonomi, budaya, dan sebagainya, Indonesia memang sedang berada di bawah hegemoni asing. Hal itu bisa dilihat dari berbagai produk undang-undang yang lebih menguntungkan pihak asing dari pada kesejahteraan rakyat Indonesia. Karena itu kemudian, jihad melawan dominasi asing ini bukanlah dengan jihad secara fisik, akan tetapi dengan jihad versi lain, semisal jihad konstitusi yang digagas oleh Muhammadiyah yang bertujuan merevisi produk undang-undang sehingga lebih prorakyat.

Pandangan kedua ormas Islam terbesar di Indonesia ini sejalan dengan pandangan ulamaulama klasik tentang batasan dâr al-Islàm dan dār al-harb. 'Abdul Qāhir al-Baghdadi seperti yang dikutip Madjid Khaddūri berpendapat bahwa wilayah yang menerima Islam tanpa terkecuali dan penguasa Islam memberikan jaminan atas kaum dhimmi disebut sebagai där alIsläm. Ulama lain berpandangan bahwa suatu wilayah dianggap sebagai där al-Isläm ketika umat dapat melaksanakan kewajibannya dengan bebas. Sementara Imam Hanafi menegaskan bahwa jika dalam suatu wilayah yang ditegakkan adalah hukum kafir, maka wilayah tersebut tidak lagi disebut sebagai dār al-Isläm, dan jika umat merasakan kesulitan dalam melakukan aktivitas ibadahnya, maka mereka harus pindahh ke dār al-Isläm (Khadduri, 2006: 155-157). Pandangan ulama klasik ini menunjukkan bahwa klasifikasi wilayah masuk ke dalam dār alIsläm ataukah där al-harb dapat dilihat dari jangkauan pelaksanaan hukum Islam dalam wilayah 
tersebut, dan bukan terletak pada penguasanya, Muslim ataukah non-Muslim. Definisi ini diterima oleh sebagian ulama Muslim selama paruh akhir abad ke-19. Sayyid Ahmad Khan dan beberapa sarjana dan ulama Deobandi dan Nadwat al-Ulamā di India adalah contoh dari mereka yang menerima definisi batasan tentang där al-Isläm dan där al-harb ini, ketika Inggris menguasai India. Demikian juga ulama NU pada masa penjajahan Belanda. Bahwa selama umat Islam bisa melanjalankan ibadahnya dengan bebas, meskipun penguasanya adalah non-Muslim, maka wilayah tersebut tetap sebagai där al-Isläm.

Adapun dār al-harb didefinisikan sebagai wilayah di mana hukum non-Islam ditegakkan, ataupun umat Muslimin tidak dapat melaksanakan ibadah dengan bebas. Ulama seperti Syaibani dan Al-Buhuti, seperti yang dikutip Madjid Khadduri, kemudian menegaskan bahwa selama tinggal di där al-harb ini tidak diperkenankan untuk ikut serta dalam memperkuat wilayah non-Islam ini dalam rangka melawan där al-Isläm, baik dalam bentuk memberi informasi pengetahuan, maupun dalam menghasilkan peralatan perang yang digunakan untuk berperang melawan Islam. Umat Muslim juga dihimbau untuk menghindarkan diri dari menikahi wanita keturunan harbi, sekalipun wanita itu adalah seorang ahli kitab, karena anakanak mereka dikhawatirkan akan melayani dar al-barb. Jika seorang Muslim melakukan hal itu, maka ketika ia kembali ke dàr al-Isläm, ia dapat dikenakan hukuman dengan tetap menghadirkan fakta dan saksi-saksi (Khadduri, 2006: 170-172).

Sementara dalam pandangan komunitas salafi, selama pemerintah belum menegakkan dan melaksanakan syariat Islam dengan kaffah, atau masih berada dalam genggaman hegemoni asing, meskipun penguasanya adalah Muslim, maka wilayah tersebut harus menjadi tujuan dan obyek medan jihad, karena dia telah menjadi dàr al-harb. Dalam pandangan mereka, penguasa Muslim yang tidak mau menegakkan syariat Islam dianggap sebagai magbut atau kafir mahaly, dan demikian jihad melawan mereka diketegorikan sebagai jibd difa $i$ yang hukumnya adalah fardu 'ain., meski untuk melakukan jihad ini diperlukan persiapan-persiapan (idad) yang matang. ${ }^{7}$

\footnotetext{
${ }^{7}$ Pandangan ini adalah salah satu doktrin dari mentor jihad mereka, yaitu Ayman Al-Zhawahiri, yang menyatakan bahwa salah satu agenda mujahidin adalah berjihad melawan pemerintahan murtad di negeri masing-masing. Lihat Solahudin, NII Sampai JI, 210, 221.
} 
Sementara dalam pandangan Imam Samudra, konflik-konflik yang terjadi di beberapa daerah di Indonesia seperti Poso, Ambon, dan sebagainya, tidaklah semata-mata disebabkan oleh adanya ketimpangan sosial dan ekonomi masyarakat setempat, tetapi lebih besar lagi konflik tersebut sebenarnya adalah bagian dari Perang Salib global, sebagai lanjutan dari konflik yang juga diciptakan Barat di Afghanistan, Irak, Kashmir, Eriteria, Pattani, Filipina, Burma, dan sebagainya. Maka umat Islam yang terlibat dalam konflik-konflik ini dengan tujuan membela dan mempertahankan diri mereka digolongkan sebagai mujābidīn fi sabīillāh. Jenis jihadnya adalah jihäd difa $i$.

Akan tetapi, Imam Samudra selanjutnya menegaskan bahwa selama ini umat Islam selalu menjadi pihak yang bertahan, sementara Barat selalu menjadi pihak yang selalu melakukan penyerangan. Dengan mengutip perkataan 'Umar bin al-Khattab r.a bahwa khairud difai i $i$ albujumu (sebaik-baik pertahanan adalah penyerangan), Imam Samudra kemudian menggagas apa yang disebut sebagai defoffensif (pertahanan sekaligus penyerangan) (Samudra, 2004: 189-190). Hal inilah yang dilakukan Imam Samudra cs dengan Bom Bali I, yang ia namakan sebagai offensif jihad.

\section{Penutup}

Dari pembacaan sejarah umat Islam tentang jihad ini, jelas bahwa umat Islam dapat memaknai konsep jihad sesuai dengan situasi dan kondisi yang mereka hadapi. Inilah bentuk dari kedinamisan makna jihad seperti yang dimaksudkan dalam teks al-Qur'an dan al-Hadis, yang dipraktikkan oleh Rasulullah Saw. dan generasi umat Islam selanjutnya. Dalam pandangan Madjid Khaduri, ada empat cara bagi umat Muslim untuk memenuhi panggilan jihad, yaitu dengan hati terutama dalam melawan bujuk rayu syetan, dengan lidah dan tangan ketika menegakkan kebenaran dan mengoreksi kesalahan, dan dengan pedang (perang) melawan musuh Islam atas nama iman (Khadduri, 2006). Dengan kata lain, jihad bisa dimaknai sebagai tindakan fisik/perang (jihad asghar) ketika umat Islam dihadapkan pada tekanan dan serangan musuh Islam secara nyata seperti yang kini terjadi dengan saudara-saudara kita di Palestina yang telah sekian lama dikangkangi zionis Israel. Akan tetapi, ketika yang dihadapi umat Islam adalah musuh yang berwujud keserakahan, kebodohan, kemiskinan, mental yang lemah dan minder, korupsi, syahwat politik yang tak terkendali, arogansi kekuasaan, dan sejenisnya, 
Jihad dinamis: menelusuri konsep dan praktik jihad dalam sejarah Islam (Zakiya Darajat)

maka jihad dalam bentuk perang fisik apalagi dengan kekerasan, tentu tidaklah tepat. Menghadapi musuh seperti ini jihad yang paling tepat adalah jihad spiritual, etis dan moral, dengan membangun kesadaran kolektif bahwa bangsa ini bisa menjadi bangsa yang besar, mandiri, dan berwibawa ketika norma agama dan sosial dipegang teguh, baik pemimpin maupun rakyat sadar akan kewajibannya masing-masing, serta terpupuk semangat untuk tetap menjadi khairu ummah, the best community.

\section{Bagan 1: Dinamisasi praktik jihad dalam sejarah Islam}

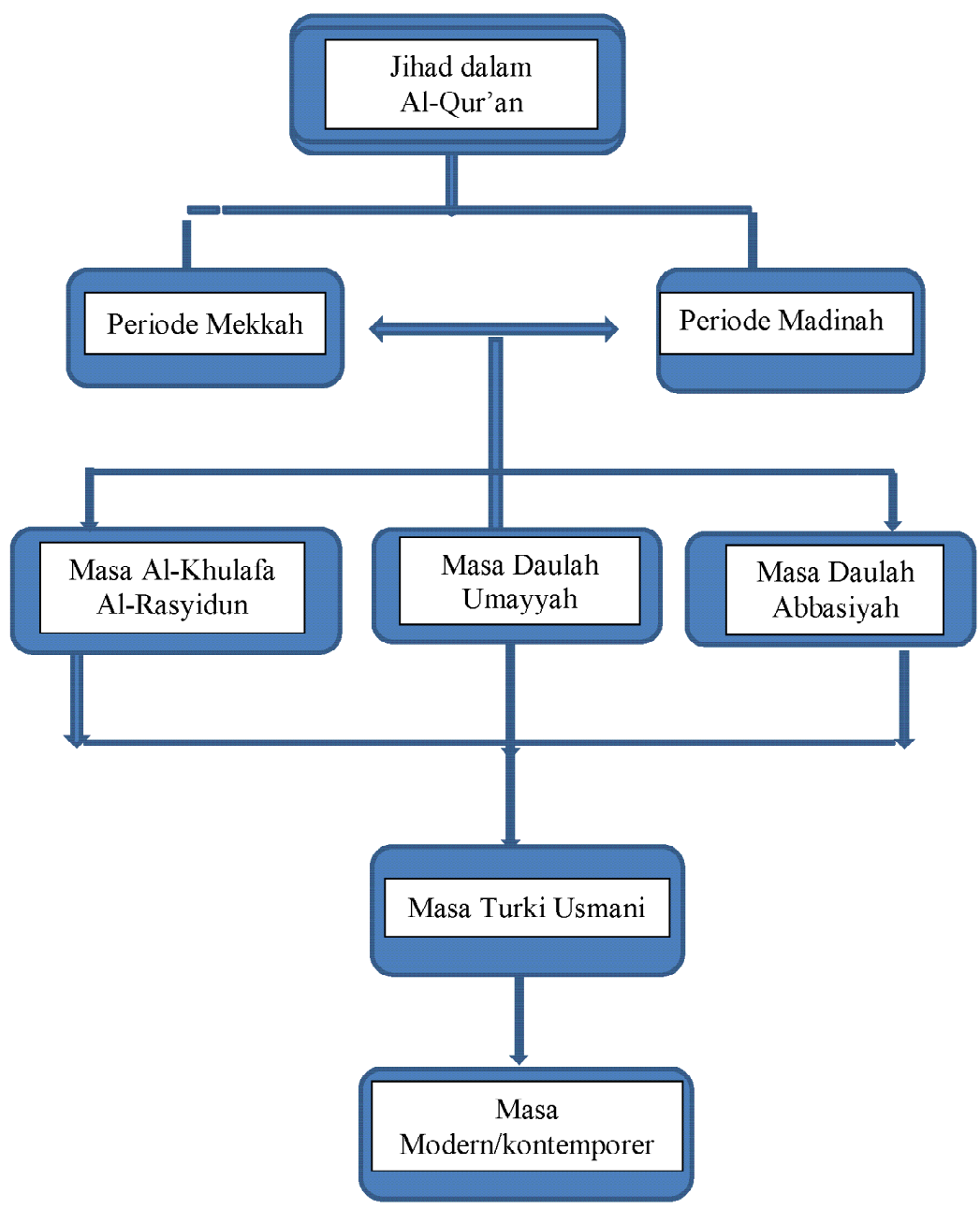


ljtihad, Jurnal Wacana Hukum Islam dan Kemanusiaan, Volume 16, No. 1, Juni 2016: 1-25

Bagan 2: Titik seteru konsep jihad
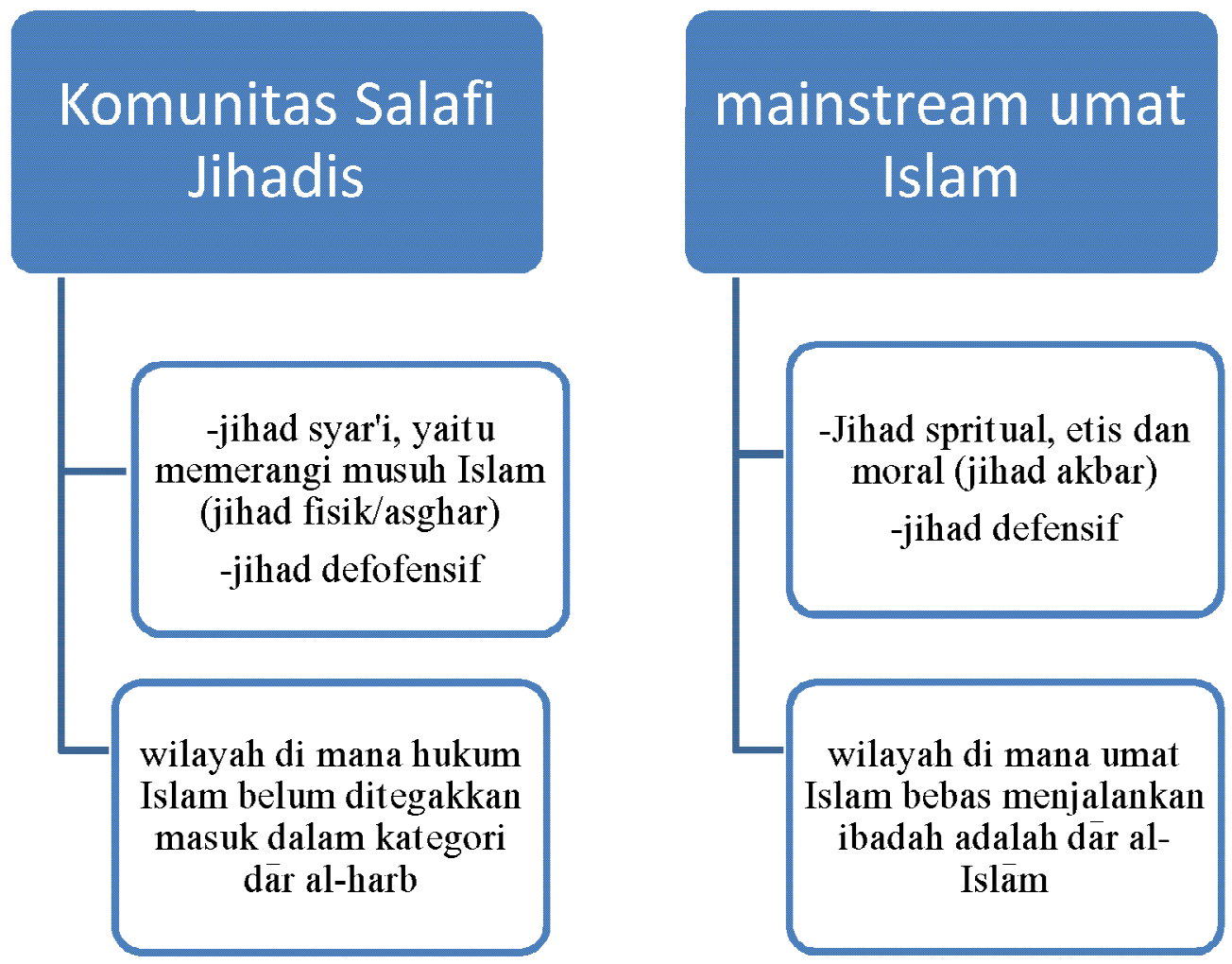

\section{Daftar Pustaka}

Al-Chaidar. Pemikiran Politik Proklamator Negara Islam Indonesia S.M. Kartosoewirjo, Jakarta: Darul Falah, 1999.

Azra, Azyumardi. Pergolakan Politik. Islam dari Fundamentalisme, Modernisme, bingga Post-Modernisme, Jakarta: Paramadina, 1996.

Barber, Benjamin R. Jihad vs McWorld, New York: Ballantine Book, 1996.

Carey, Peter. The Power of Prophecy; Prince Dipanegara and The End of an Old Order in Java, $1785-$ 1855, Leiden: KITLV Press, 2007.

Euben, Roxanne, L. "Killing (for) Politics, Jihad, Martyrdom, and Political Action" (Sage Publication, Vol. 30, No. 1, (February 2002). 
Jihad dinamis: menelusuri konsep dan praktik jihad dalam sejarah Islam (Zakiya Darajat)

Enizar, "Jihad dalam Perspektif Hadits Rasulullah Saw.", Disertasi UIN Jakarta, 2002.

Fealy, Greg, "Islamic Radicalism in Indonesia; The Faltering Revial?", Institute of Southeast Asian Studies, 2004.

Khadduri, Madjid. War and Peace in The Law of Islam, New Jersey: The Johns Hopkins University Press, 2006.

K. Hitty, Philip, History of The Arab, (London; McMillan, 1970).

Kiram Mashuri, Ikhwanul, ISIS Jihad atau Petualangan, Jakarta: Republika, 2014

Lewis, Bernard. The Political Language of Islam, Chicago: The University of Chicago Press, 1988.

Heck, Paul L., "Jihad Revisited", The Journal of Relogious Ethics, Vol. 32, No. I, (2004) http:/ /www.jstore.org/stable

Roshandel, Jalil, and Sharon Chadha. Jihad and International Security, New York: Palgrave Macmillan, 2007.

Said, Edward W. Covering Islam: How Media and The Expert Determine How We See The Rest of The World, New York: Vintage, 1997.

Samudera, Imam. Aku Melawan Teroris!, Solo: Jazeera, 2004.

Samudera, Imam. Sekuntum Rosela Pelipur Lara, Jakarta: Ar-Rahmah Media, 2009.

Turner Johnson, James. The Holy War Idea in Western and Islamic Traditions (terj), Yogyakarta: Qalam, 1997.

Watt, Wontgomery W, The Majesty That Was Islam, (teri), (Yogyakarta; Tiara Wacana, 1990). 